\title{
Work and Family Directions in the US and Australia: A Policy Research Agenda
}

\author{
Robert Drago*, Rosanna Scutella\# and Amy Varner* \\ *Penn State University \\ \#Melbourne Institute of Applied Economic and Social Research \\ The University of Melbourne
}

Melbourne Institute Working Paper No. 12/02

ISSN 1328-4991

ISBN 0734015364

July 2002

* Without implicating them in any errors, thanks to Anne Bardoel, Peter Dawkins, Matthew Gray, David Johnson, Guyonne Kalb, Peter McDonald, and Mark Wooden for valuable advice along the way. Many of the arguments below were developed jointly with Lotte Bailyn and Tom Kochan for the Sloan Work/Family Policy Network, funded by the Alfred P. Sloan Foundation. We would also like to particularly thank the Department of Family and Community Services for funding this research. The views expressed in this paper are those of the authors and do not represent the views of the Minister for Family and Community Services, the Department of Family and Community Services or the Commonwealth Government.

Melbourne Institute of Applied Economic and Social Research

The University of Melbourne

Victoria 3010 Australia

Telephone (03) 83443701

Fax (03) 83445630

Email melb-inst@unimelb.edu.au

WWW Address http://www.melbourneinstitute.com 


\begin{abstract}
This paper provides a comparative glimpse of work/family issues in Australia and the US. It begins with a summary of an emerging vision of ideal policies and practices for work and family. The paper then provides historical background for the recent emergence of a 'care gap' in both countries, focusing on key commonalities and differences. The current status of the gap and the related 'default solution' to the gap are then outlined. Key commonalities here include an increasing diversity of family forms, a rise in delayed and denied childbearing, and substantial gender inequality. Significant current divergence across the societies includes relatively more family-responsive governmental policies in Australia, more attractive part-time opportunities for mothers in Australia, a relatively more equal division of labor in the home in the US, a greater prevalence of corporate-sponsored work/family policies in the US, and greater coverage of Australian employees by work/family policies negotiated through enterprise agreements. A tentative research agenda is provided in conclusion, focusing on part-time employment options, work incentives and child care for single parents, the causes of delayed and denied childbearing, and enterprise bargaining and corporate policies.
\end{abstract}




\section{Work and Family Direction in the US and Australia: A Policy Research Agenda}

This paper provides a comparative glimpse of work/family issues in Australia and the US using existing studies. Policies, both governmental and private, are detailed to highlight differences, similarities, and opportunities for each society to learn from the other. Potential avenues for new, policy-oriented research are explored with an eye towards the creation of comparable data across the two nations.

\section{Introduction}

In both Australia and the US, much public policy surrounding employment, wages and working conditions was built upon the model of 'separate spheres' (Bailyn, 1993; MossKanter, 1977; Williams, 1999). According to the model, husbands worked for wages in the public sphere, while wives served as unpaid housekeepers and child rearers in the private sphere of the home. Status, power, wealth and income were associated with the public sphere, while love, care, and low status tasks were relegated to the private sphere.

Although the model of separate spheres continues to be embodied in many public and private sector policies, and to influence behavior, norms and expectations across the two societies, the key objective condition underpinning the model no longer exists. As of this writing, over 40 percent of employees in the US and in Australia are women, and in both countries a majority of mothers of dependent children are employed. Nor has either country witnessed a corresponding decrease in male employment nor a return of fathers to the home for child rearing and housekeeping purposes of anywhere near the scope that would be required to make up for the historical loss of the unpaid hours of work provided in the home by women. The result is a 'care gap,' (Harrington, 1999) wherein families, governmental bodies, employers and labor organizations, and community and non-profit organizations are left scrambling to figure out how to make up for the loss of unpaid labor. The result is a very uneven system of care, where many parents believe that organized childcare is either or both of low quality and unaffordable, where many parents are forced to have children return from school to an empty house, and where caregivers receive low or no wages. The brunt of this care gap has fallen upon families who have attempted to either increase their unpaid child care time or avoided child rearing responsibilities entirely, and the burden has fallen 
particularly hard upon women as caregivers (both paid and unpaid) for children, the disabled, and the elderly.

The resulting problems are ultimately complex, in part due to issues such as the increasing diversity of families in both societies, and the on-going internationalization of both economies in tandem with the rapid expansion of information technologies. Nonetheless, a consensus seems to be emerging from the work/family literature regarding core values and policy objectives (Bailyn, 1993; Crittenden, 2001; Deutsch, 1999; Dowd, 2000; Folbre, 2001; Fried, 1998; Glass, 2000; Harrington, 1999; Heymann, 2000; Hochschild, 1997; Lakoff, 1996; Risman, 1998; Russell \& Bowman, 2000; Stone, 2000; Williams, 1999). The core values include the following:

- Individuals have the right to a life where they can successfully meld responsibilities to paid employment and to their families, and

- Care for children and other dependents should be valued.

The vision of work/family flowing from these values is one where individuals are able to simultaneously make commitments to both work and to family, and to adjust their work and family commitments over the life course. For some examples:

- Individuals should be able to take some paid time off following the birth or adoption of a new child, without cost to the employer, and regardless of the particular family structure.

- Individuals with particularly heavy responsibilities, including those associated with very young or special needs children, disabled partners or spouses, and seriously ill elders, should be supported financially at a reasonable level, and be provided with meaningful opportunities for employment when and if those responsibilities lessen.

- Careers should be structured, and work designed, such that opportunities to reduce hours for short or long duration caregiving responsibilities do not result in loss of employment and promotion opportunities.

- Penalties currently associated with occupations involving a significant amount of caregiving (e.g., nurses, teachers, and child care providers), should be eliminated, while the quality of care is raised to a reasonable standard across each society. 
- Men and women should perform an equal amount of caregiving and housekeeping labor in the home.

Although this agenda for policy and practice sounds ambitious, it is hardly utopian, as many of the pieces are currently falling into place in both Australia and the US. Moreover, much as some might wish for a return to a more patriarchal past (Fukuyama, 1999), neither economy could survive a massive withdrawal of women or mothers from their labor forces. Therefore, the current situation in both countries can be cast in terms of an institutional lag, whereby various institutions require updating to fit current conditions.

Note further that this vision does not specify an ideal family type. Families have become more diverse, and will likely continue to do so. What the vision does specify is environments that are fair in terms of the burdens of paid and unpaid work, and where individuals are in a superior position to make and meet commitments to both family and work.

The research agenda associated with this vision involves the testing of linkages between desired outcomes and various policies and characteristics of families, governments, employers, labor and community organizations, and social infrastructure. Some of these linkages are straightforward, as in the relationship between tax supports for caregivers and levels of caregiver poverty. Others are far more complex, with perhaps the most well known example being the very tenuous association between formal employer provision of parental leave policies and utilization of those policies (Fried, 1998; Hochschild, 1997).

Two further considerations should shape research on work and family policies. First, it is crucial to ascertain whether specific policy options will be viewed as fair by the general public. Recent research suggests that the 'backlash' against work/family policies promoted by the media and others (e.g., Burkett, 2000) is almost certainly overblown (see Drago, et al, 2001, and citations therein). Nonetheless, there are significant differences in levels of support for work/family policies across groups who are and are not likely to use the policies (Drago, et al, 2001). The ability to successfully promote and initiate work/family policies, whether individuals feel free to use the policies, and even the long-term viability of such policies hinges upon ensuring that they are perceived as fundamentally fair. 
Second, the success of policy initiatives hinges in large part on whether the burdens placed on specific institutions are consistent with the objectives, viability, and success of each institution. For example, requiring employers to provide paid family leave for employees effectively penalizes employers with large numbers of employees with elder care responsibilities, making those firms less competitive. Very differently, requiring parents to return to full-time employment soon after a new child is born may have deleterious effects upon children.

\section{Background}

In both Australia and the US, employment relations, the educational and social infrastructure, and relevant governmental policies were historically built upon the foundation of separate spheres. Related to this, jobs for working class men and careers for professional men followed the assumption that men should be breadwinners. These structures in turn provide crucial context for understanding the specific ways in which the care gap emerges in each country.

In Australia, the breadwinner assumption was enshrined in the "basic wage" as specified in the Harvester case of 1907. The basic wage for an adult male performing unskilled labor was defined as that which would provide sufficient income for a family of five if the employee worked full-time (Davis and Lansbury, 1998). The basic wage represented an attempt to ensure that families would not need to place women and children in the labor force. Further, female wages were set at 54 per cent of the male wage.

Related policies in Australia were consistent with this approach. Prior to September 1994, the "breadwinner" was the only member of a couple that had to satisfy the activity test for unemployment benefits (i.e. to search for and be available for full time work) and would receive the payment on behalf of the entire family.

In the US, these assumptions were not directly embodied in the "minimum wage" provisions of the Fair Labor Standards Act of 1938. Those provisions were instead intended to ensure that, on the one hand, unskilled workers would receive a wage sufficient to pull them near or above the poverty line and, on the other hand, to reduce the possibility of wage competition 
by non-male, non-breadwinner employees who could afford to work for a lower wage (i.e., women, youths, and non-parent men).

The more far-reaching provisions of the Act concerned the standardization of working time on the 40 hour week (44 hours in the original Act, amended to 40 in 1940), and particularly the overtime provisions of the Act. These provisions specified a 50 percent hourly wage premium for all hours beyond 40 in any given week for non-salaried employees. The most direct consequence of the Act was that employers slowly moved many employees over to salaried status wherein earnings were fixed regardless of hours. An indirect consequence was that the 40 hour week became a social norm, and US employers tied the provision of benefits, particularly health insurance and pensions, to full-time employment status (Drago, 2000). There is nothing in the Act specifically linking full-time status to the provision of benefits and of higher hourly wages, but the result occurred nonetheless.

Breadwinner assumptions were directly placed into collective bargaining agreements negotiated between organized labor and employers in the US. In their heyday in the 1950's, such agreements covered around one-third of the US workforce, and at the center of these agreements lay the notion of seniority. Under seniority provisions, uninterrupted employment is rewarded with higher wages, promotion opportunities, greater retirement earnings, and enhanced job security. By design, breadwinning men were uniquely situated to take advantage of seniority provisions, while employees who took time out of the labor force for caregiving responsibilities were penalized with the loss of seniority rights.

In both countries, but especially in the US, regulations surrounding employment and benefits produced a relatively high fixed cost for full-time employees. In the US, fixed costs included training, health care insurance and pensions; health care costs are not relevant to employers in Australia, and pro-rated pension payments were provided to casuals as of the early 1990s. Additional or non-standard hours resulted in higher hourly wages (i.e., overtime pay or premia), but with high fixed costs, it was often more economical to work full-time employees long hours than to hire part-time employees. This is particularly true in both countries with regard to salaried professionals, where the marginal cost of an additional hour of work is effectively zero so long as the employer can motivate the employee to provide the hour of work. 
High fixed costs implied that employers in both countries had little reason to create shorthours jobs. Nor did employers have any strong incentive to structure careers such that interruptions for family commitments are the norm.

Fixed costs do not provide a complete explanation for the emergence of long-hours and uninterrupted employment as the norm for careers in Australia and the US In addition, we need to consider the role of the "ideal worker" norm (Williams, 1999). Initially described by William H. Whyte (1954) as applying to men on their way up the organizational ladder, women who entered careers found themselves facing and adapting to the same set of expectations (Bailyn, 1993; Hochschild, 1997; Williams, 1999).

The importance of the ideal worker norm for present purposes is two-fold. First, the norm is inconsistent with any significant time commitments for caregiving. Second, the expansion of the norm cross-nationally may help to explain the increase in average working time among high-earning, professionals in both Australia and the US during the last two decades (see Wooden, 2001, and Drago, 2000, respectively).

During this period, the increase in working time at the top end of the labor market was mirrored by a decline in working time among low-wage employees. Partly as a result, earnings inequality increased in both countries. The major difference here is that income inequality per se grew much more rapidly in the US, while unemployment became pervasive and often of long duration among low-skill Australians (McClure, 2000), and perceptions of job insecurity remained high across much of the Australian labor market (UMR Research Party, 2001).

The similarities outlined above provide much of the context for the emergence of the care gap in both countries. However, four key historical differences shaped initial responses to the care gap. These concern approaches to part-time employment, health care financing mechanisms, governmental provision of welfare benefits, and coverage by collective agreements.

1) The treatment of part-time employment per se, is quite different in Australia and the US. In both countries, it can be argued that trade unions fought against the emergence of part-time 
employment arrangements, believing that such arrangements would threaten the breadwinner model of employment and therefore the men who historically comprised the vast majority of union members in both countries. The strategies employed to oppose part-time employment, however, were very different. In the US, unions attempted to make part-time employment economically unattractive to employees. The resulting lower wages (Budig and England, 2001), absence of job security, and widespread shortfall of health care and pension benefits for part-time employees in the US (Williams, 1999), demonstrate the success of these attempts. In addition, many collective bargaining agreements have historically restricted the number of part-time positions an employer may create. In Australia, trade unions strove to make part-time employment unattractive to employers through the casual loading, a wage premium (typically around 20 percent) paid to most casual employees and to most part-time employees (who tend to be casual) in lieu of vacation, sick time, and pension benefits. In addition, and parallel to the US experience, many awards historically restricted the conditions under which part-time jobs could be created, restrictions which were loosened in recent years. Even with the casual loading affecting most part-time employees, recent Australian evidence suggests that lifetime lost earnings for women who have even one child is in the order of $\$ 115,000$ for women without a high school diploma, and $\$ 510,000$ for women with a college degree (Chapman, et al, 2001). Crittenden (2001) suggests the comparable figures for college educated women in the US are far higher.

2) Health care financing is also distinct in Australia and the US. In the latter country, health care insurance is closely linked to employment and particularly full-time, permanent employment. As a result, 50 million US citizens currently have no health insurance. Groups disproportionately represented among those without health insurance include children, parttime employees, job changers, and the unemployed. Australia provides public health insurance that is not financed by employers. These approaches to health care financing raise the fixed costs per employee facing employers in the US relative to Australia.

3) Both Australia and the US historically provided a system of income and benefit support systems for individuals who would otherwise live in poverty, and particularly for poor mothers (see McClure, 2000, and Albelda and Tilly, 1997, respectively). Further, both systems limited such support to non-employed individuals living in households with low income. Nonetheless, the Australian system has traditionally been far more generous, and 
income supports were not, and are not, dependent upon past employment or marital history. In the US, by way of contrast, the most generous welfare provisions were traditionally for widows and for adults who lost their jobs through no fault of their own (i.e., the Social Security and Unemployment Insurance systems). During the 1990s, welfare was reformed in both countries in an effort to link support to attempts by able-bodied adults to obtain and hold employment.

Among remaining differences across the income and benefit support systems, at least two are important for present purposes. First, the Australian system currently has no work requirements or time limits on the receipt of income support payments for single mothers of dependent children, while recent welfare reforms in the US include both work requirements and time limits. Second, the US system continues to have a major employment disincentive in that health care insurance supports are pulled as family income rises even minimally above the poverty level. ${ }^{1}$

4) Both Australia and the US have experienced dramatic declines in union membership during the last half-century. As of 2000, only 13.5 percent of all employees, and 10 percent of private sector employees in the US were union members (BLS, 2000b). In Australia, trade union membership dropped from around half of all employees in the mid-1970s, to 25 percent by 2000 (ABS, 2000a, Table 15).

Where the countries diverge more significantly is in the rate of coverage by collective agreements. In the US, union membership figures tend to align closely with coverage by collectively bargained contracts. In Australia, between 35 and 48 percent of employees are covered by enterprise agreements (Wooden, forthcoming), while The Award and Agreement Coverage Survey 1999 found that 86 percent of all employees in businesses with at least five employees are covered by awards (Joint Governments Submission, 2000, Table 5.7), a figure that undoubtedly overlaps much if not all of employees covered by enterprise agreements. The importance of the divergence in coverage by collective agreements in Australia as

\footnotetext{
1 The Clinton administration increased health care funding for poor children during the late 1990s, and individual states can implement different cut-offs for health care benefits under the 1996 PRWOA legislation, so the situation is slightly more complex than suggested in the text.
} 
opposed to the US for present purposes lies in a greater ability to implement policy changes through such agreements in Australia, as indeed happened.

\section{The 'Default Solution'}

With the context above, we can now consider the specific shape that the care gap takes in each country. The care gap emerges as what is here labelled the 'default solution,' wherein earlier institutions built around the breadwinner model remain intact while work/family circumstances have changed.

Commonalities across the two societies are as follows:

1. Family forms have become more diverse as the incidence of divorce, non-marriage partnerships, and single-parenthood have risen in each country (Bond, Galinsky, and Swanberg, 1998; Russell and Bowman, 2000). Who requires care within the family, and who is available to provide care have therefore taken on more diverse patterns across families over time. In part, though not entirely, the increase in the diversity of family forms is due to the emergence of the care gap, as the economic value of men to (now employed) women has fallen, while the likelihood of men filling the care gap within any particular family has increased only marginally (although see Deutsch, 1999; Schor, 1998).

2. Delayed and denied fertility have become far more prevalent, particularly among highly educated women. Evidence from both the US (Varner and Drago, 2001) and from Australia (Barnes, 2001) suggest that many women are increasingly viewing work and family as an "either/or" proposition, therefore delaying or abandoning attempted childbirth in the belief that employment security and promotion opportunities would be endangered following the birth of a child. In both countries, the expectation that men will have careers and families remains intact, and is not viewed as a trade-off, but this is not the case for many women. McDonald (2000) traces declines in fertility across a variety of countries to the 'default solution,' since rates of fertility are lowest in countries where the institutional lag is more severe, where neither men nor government agencies nor other institutions provide substantial supports for caregiving. 
There are three reasons to view delayed and denied fertility as social problems. The first, affecting delayed childbearing only, is that health care costs systematically rise with the age of the prospective mother because of risks to the child, risks to the mother, and infertility treatments (detailed in Varner and Drago, 2001). The second is that delayed and denied childbearing are arguably unfair, as signaled by the lop-sided distribution of the phenomenon across employed women and employed men. The third reason to view these as problems is that the employment and hence tax bases of Australia and the US, particularly relative to pensioners, is shrinking.

As Barnes (2001) argues, both countries have responded to the last-mentioned problem in part through a heavy reliance upon immigration. They will become more dependent as they struggle to shore up their tax bases in response to the aging of their populations and resulting financial burdens on public support systems. In what is already shaping up as an international 'war for immigrant talent,' the US probably enjoys substantial advantages. Nonetheless, neither country can view immigration as a complete solution, since the numbers do not add up. A reversal of delayed and denied fertility could ameliorate this emerging war for talent.

3. The bulk of unpaid caregiving continues to fall upon the shoulders of women. What Arlie Hochschild (1989) labeled the "second shift" of unpaid housework and childcare performed by employed women, continues to exist both in Australia and the US (see Bittman, 1999, and Sandberg and Hofferth, 2001, respectively). Such an outcome is not only inequitable but arguably unsustainable (see 2. above).

In addition, recent studies find little divergence in the determinants of whether firms in Australia and in the US offer work-family benefits (Bardoel, Tharenou, and Moss, 2001), even though the overall extent of such provisions differs markedly (see below).

Although the following is very preliminary, it appears that the following differences exist across the two societies:

1. Governmental policies are relatively more family-responsive in Australia. For example, although neither country provides for paid parental leave, new parents with permanent employment (either full-time or part-time) are guaranteed a full year of shared unpaid leave compared to only 12 weeks in the US. A recent AIRC (Australian 
Industrial Relations Commission) decision also allows long-term casuals parental leave. Paid maternity and paternity leave is available in the public service and is also becoming much more common in the private sector in Australia. Further, subject to means testing, Australian parents may be entitled to receive an income support payment for parenting (Parenting Payment), an additional benefit for raising dependent children (Family Tax Benefit), and a benefit to help with child care costs (Child Care Benefit) (see Appendix), all of which lie above the basic federal provision in the US (i.e., the Earned Income Tax Credit), and none of which take the regressive form of the US federal income tax deduction for dependent children. Further, state welfare-to-work policies under the PRWOA (Personal Responsibility and Work Opportunity Act) of 1996 in the US tend to force even mothers of very young children into the labor force, often leaving even those receiving welfare benefits living under extreme hardship (Bushey and Gunderson, 2001) and forcing children into dangerous child care arrangements (Benet, 2001). In Australia, very differently, currently no work requirement is imposed on welfare recipients (e.g., poor, single mothers) until a child is 16 years of age (see Appendix). Some additional requirements on recipients of Parenting Payment have been announced in the 2001/2002 Commonwealth Budget; however, they are nowhere near as extreme as those in the US. If passed through the Senate the changes will require Parenting Payment recipients with children thirteen years and over to undertake an average of six hours a week of activities designed to help them return to work. Recipients with children aged over six years would be required to attend an annual interview to help prepare them for re-entry into the labour force in the long term. Also, the Jobs, Education and Training Scheme introduced in 1999 for recipients of Parenting Payment in Australia is aimed at assisting parents to re-enter the labour market.

Labour force participation rates for lone parents in both Australia and the US have risen in recent years (ABS, 2000b and US Department of Labor, 1999). This change enhances the importance of policies designed to permit simultaneous commitments to family and work. Recent discussions in policy circles have centered around introducing a work incentive payment in Australia, much like the Earned Income Tax Credit in the US, which is expected to have further positive effects on labour force participation for lone parents in Australia. 
2. Reduced-hours arrangements are relatively attractive in Australia. As mentioned earlier, part-time employment typically implies a lack of health care insurance or pension benefits, and a lower hourly wage in the US, while part-time employees in Australia receive full health care benefits, and pensions are not related to employment history. These differences have contributed to much higher rates of part-time employment in Australia. Although the figures are not perfectly comparable 5.6 percent of women in the US were employed part-time in 1999, while the Australian Labour Force Survey shows that close to 23 percent of Australian women were employed part-time as of May 2001, in both cases using a cut-off of 35 hours per week or less to define part-time employment (figures constructed from BLS, 2000a, Table 1 and ABS, 2001a, Table 2 respectively). Of women employed, 27.7 per cent worked part-time in the US compared to 44 per cent in Australia. Although such arrangements may serve to reduce levels of conflict between work and family (Williams, 1999), Moen and Yu (2000) note that existing gender inequality may be extended and resolidified through these "neotraditional" families where the woman continues to perform most unpaid work in the house and holds a subordinate position in the labor market. Consistent with the latter view, a recent Australian survey found 66 percent of part-time and casual workers reporting increased difficulties in balancing work and family relative to a figure of 55 percent for full-time employees (see UMR Research Party, 2001). This difference is intuitively odd, since many parttime employees may take such positions specifically to achieve a better balance between work and family commitments. However, most of the accommodation here seems to fall on women. For example, Bardoel, Tharenoux, and Ristov (2000) report that out of employed parents, over one-half of all Australian mothers work part-time, while only 5 percent of fathers do so. What may be going on is that part-time employment for mothers worsens the division of labour in the home by giving fathers an excuse to avoid housework; simultaneously, family income and the opportunities to purchase childcare and housework may be reduced following a switch to part-time employment.

Note that the growth in part-time employment in Australia during the 1990s was mainly associated with females, which may largely be associated with women trying balance their work and family life (ABS, 2001b). 
3. The gender division of labor in the home is more unequal in Australia. The higher rate of part-time employment among mothers in Australia may have increased the opportunities for Australian men to keep the second shift firmly placed on the shoulders of women. For example, Glezer and Wolcott (2000) summarize Australian time use studies suggesting that among heterosexual couples, men typically spend half as much time on housework in general, and a tiny fraction of the time women spend on low-control tasks such as laundry, ironing, and clothes care. While Barnett and Rivers (1998) report that such differences remain in the US, the magnitude of the divergence is smaller.

4. Corporate policies are far more prevalent in the US. Although a wide variety of evidence suggests that it remains difficult for employees to use policies in the US, work/family policies are more common. For example, Russell and Bowman (2000) summarize a variety of evidence showing that corporations in the US, relative to Australia, are at least twice as likely to offer on-site child care, after school care, child care or elder care resource and referral services, nursing rooms, seminars for employees with family issues, and compressed workweeks. Australian corporations led in the provision of part-time work (92\% compared to $69 \%$ ) and in the ability of employees to use sick days to attend to family commitments.

5. Some collective agreements in the US are very advanced; nonetheless, the widespread extent and certain key features of Australian agreements tend to make Australia more family-responsive. Because coverage by collective agreements in the US is so limited, the impact of unions and such agreements on the average US employee is also limited. Nonetheless, many recent agreements in the US are extremely impressive in the scope, depth, and financial commitment to work/family issues. For examples, see the Labor Project for Working Families web site (http://laborproject.berkeley.edu/), or the Ford-UAW Family Service and Learning Centers (http://www.familycenteronline.org/). The latter provides services ranging from on-site to subsidized child care, retirement programs, after-school care, and continuing education. By way of contrast, workplace agreements in Australia include more limited work/family provisions that cover numerous employees. The 1996 Workplace Relations Act was designed to facilitate workplace agreements promoting "more innovative work styles and working patterns that balance work and family responsibilities more effectively."(DEWRSB, 1999) At present, it appears that most 
paid maternity and paternity leave in Australia is provided through such agreements, and awards provisions were recently extended to provide maternity leave to some casual (or temporary) employees (see www.actu.asn.au).

\section{A Comparative Research Agenda}

The glimpse at work and family in two societies provided here opens up an array of potential avenues for comparative research. These include:

1. Survey and case study research on the long-term consequences of part-time employment for parents. If reduced hours arrangements are to serve as genuine options over the life course, with individuals flowing between part-time and full-time employment as needed, an understanding of the long-term consequences of part-time employment is required. For example, data from the first wave of the HILDA for Australia and from the 1997 National Study of the Changing Workforce for the US could be used to answer many of the following questions:

a. Do the preferred hours of employees decline when young children or elder care responsibilities appear? If so, do those hours increase as children age and elder care responsibilities ease?

b. If the prior questions are answered in the affirmative, then we would ask whether working hours change in response to changing employee hours preferences. Preliminary evidence from Australia (Willis, 1997) suggests that two problems may exist: i) movement from part-time to full-time employment may be 'non-convex' or lumpy, such that a very limited range of choices exist in terms of hours arrangements, and ii) employers may tend to relegate parttimers to long-term part-time status. In either case, the types of occupations that do and do not facilitate movement between full-time and part-time status should be explored. Further, it would be useful to know whether it is easier to switch from part-time to full-time status in the US, where part-time is less common, or in Australia, where the phenomenon is far more wide-spread.

c. Existing longitudinal studies in the two countries have not asked whether parttime status for even a relatively short period of time reduces promotion opportunities for a matter of years, or if instead the effects disappear over 
time. For those contemplating part-time options, knowledge of long-term effects would be extremely useful.

d. Do appropriate employer policies facilitate part-time options for career employees? At present, related research has begun in the US (see, e.g., www.pardc.org), but more is needed both there and in Australia.

e. How do part-time arrangements affect the division of labor in the home? Although a connection between the part-time employment of mothers and the second shift seems reasonable to suggest, no evidence for the linkage exists in either Australia or the US

f. Related to the above, what conditions or policies are related to the utilization of part-time work arrangements by men, and particularly fathers? At present, the number of men using such arrangements appears to be small, so case study rather than survey methods might prove most fruitful for analyzing the issue.

2. Work incentives and child care for single parents. The overarching structure of supports for poor, single parents in Australia and the US seems to favor parenting in Australia and paid employment in the US. The US system seems relatively putative (e.g., Bushey and Gunderson, 2001), and harsh both in terms of family living standards and the time available for family relationships, while the Australian system allows long-term non-employment for poor single mothers, but much time for family relationships (see Appendix). Improvements to both systems might move each somewhat closer to the other, enhancing standards of living and family time in the US, while increasing work incentives in Australia.

The Appendix provides information on some of the basic income supports and work incentives for parents in Australia and the US. Other Australian research shows that these incentives have predictable labor force participation effects on both single parents (Duncan and Harris, 2001) and members of couples (Kalb, 1999).

One opportunity for policy experimentation lies in part-time employment. As Kalb (2000) has found using Australian data from the mid-1990s, there has been a substantial penalty associated with part-time employment for women. Particularly for the parents of school-aged children, improving opportunities for and reducing the penalties associated with part-time employment might result in greater work experience among those leaving income support systems as children become 
independent. In turn, such work experience might lend itself to more positive labor market outcomes (e.g., higher wages and more stable employment) among those leaving the system. Existing research has established the parameters for estimating the likely effects of pursuing such policies, but the estimates need to be derived.

It might also be worthwhile to simulate the effects of such policies for specific states in the US (welfare programs are now state specific in the US, see the Appendix for relevant examples). At present, to the best of our knowledge, welfare-to-work programs in the US are exclusively built around full-time employment opportunities. However, better outcomes for families, and superior long-term employment experiences, might result from pursuing part-time employment options, particularly for the parents of school-aged children.

3. The causes of delayed and denied childbearing. The evidence presented earlier suggests that many women in Australia and the US, particularly highly educated women with career aspirations, find traditional employment inconsistent with childbearing and childrearing. Initial evidence from the 2000 census in the US suggests that Hispanic and Asian minorities are holding up the birthrate there, but further research is required to ascertain whether educated women in these groups also generate high levels of fertility of if, instead, lower levels of average education are responsible. If the latter is true, as is suspected, then research is needed to identify the conditions under which highly educated women feel free to bear children and maintain a career (i.e., to neither delay nor deny childbearing). Different types of data could be used to identify these conditions, since they might include:

a. Working time arrangements, the organization of the workplace, and the culture of the workplace with respect to work and family.

b. Occupation- and industry-specific conditions.

c. The likely contributions of men towards parenting time and housework.

d. Tax- and related financial supports for working parents.

4. Enterprise bargaining and corporate policies. A crucial problem for those promoting a work/family agenda has been the low rates of utilization associated with the presence of even very generous and flexible corporate policies (Fried, 1998; Hochschild, 1997). It seems possible that the provision of such policies through enterprise awards might have the effect of increasing utilization rates. One reason for 
positing such a connection lies in the distinction between benefits and rights. To the extent enterprise agreements transform policies from benefits to rights, as suggested by Gerstel and Clawson (2000), knowledge of and utilization of policies might increase. Related research could:

a. Compare workplaces with similar corporate-initiated as opposed to collectively agreed policies to ascertain whether policy utilization is higher in the latter case. For Australia, the value of such research would lie in identifying the importance of codifying such policies in agreements. For the US, the value of such research would lie in establishing whether union membership facilitates family-responsiveness in the workplace.

b. Compare policies across workplaces covered and not covered by agreements with substantial family-responsive components to identify differences in the types of policies existing under the two different regimes. It seems likely that higher-cost policies, (e.g., subsidized or on-site childcare), are more likely to appear under agreements, while relatively low-cost arrangements favoring high-income employees (e.g., concierge services) may otherwise appear. Existing research can neither confirm no deny this possibility.

5. The Division of Labor in the Home. There has been a marked increase in the US in the time fathers spend on parenting during the last three decades. Efforts to promote a more equal division of labor in the home, particularly around childcare, would benefit from research doing the following:

a. Identify the types of families where unpaid work is more equally divided, and the characteristics of men who do and do not spend time with their children in terms of education, occupation, ethnicity and country of origin, and working hours.

b. Locate changes in this division of labor over time, and for whom those changes are taking place.

While the research opportunities outlined above may help to provide some direction for future endeavors, the field of work/family is inherently interdisciplinary. Other disciplines could most certainly generate research of use for policy-makers. For example, case law around the family provisions of the 1996 Workplace Industrial Relations Act is still 
developing, and is worthy of study. In the US, legal challenges to wage and career structures that arguably discriminate against parents are currently being considered (see Williams, 1999). In both societies, many work/family policies have been structured around a gendered model of the labor market - through the Pregnancy Discrimination Act in the US, and through widespread pregnancy leave provisions in Australian enterprise agreements. A comparative study of the legal and industrial relations developments could shed light on opportunities to strengthen existing policies and practices, and to break down the gendered nature of work and family in the two societies.

Very differently, the language employed in conversations around work and family is, in both societies, very much contested (Williams, 1999; Maushart, 2001), leading to charges that work/family policies are unfair (Burkett, 2000). It is possible that less divisive and more fair and productive language could be discovered and promoted through comparative linguistic and ethnographic studies (see, e.g., Lakoff, 1996, and Garey, 1998, respectively).

In sum, there exist numerous opportunities for comparative research to expand our understanding of the shape of work/family conflict, to enhance existing policies and practices, and to identify new opportunities to create better workplaces, homes and societies. 


\section{References}

Albelda, Randy P., and Tilly, Chris. (1997). Glass Ceilings and Bottomless Pits: Women's Work, Women's Poverty. Boston MA: South End Press.

Australian Bureau of Statistics (2001a). Labour Force, Australia, Preliminary, Catalogue No. 6202.0, May.

Australian Bureau of Statistics (2001b). "Special article: Full-time and part-time employment", in Labour Force, Australia, Catalogue No. 6203.0, October, available online at http://www.abs.gov.au/ausstats/abs@.nsf/Lookup/NT0001DC1E.

Australian Bureau of Statistics (2000a). Employee Earnings, Benefits and Trade Union Membership, Australia, Catalogue No. 6310.0, August.

Australian Bureau of Statistics (2000b). Labour Force Status and Other Characteristics of Families, Australia, Catalogue No. 6224.0, June.

Bailyn, Lotte. (1993). Breaking the Mold: Women, Men, and Time in the New Corporate World. New York: Free Press.

Bardoel, E. Anne, Tharenou, Phyllis, and Ristov, Douglas. (2000). "The Changing Composition of the Australian Workforce Relevant to Work-Family Issues," International Human Resource Issues, 1(1), 58-77. , and Moss, Simon. (2001). "Work-Family Practices and Accommodating

Work-Family Workplaces: A Combined Institutional and Resource Dependent Theory Explanation," Working paper 31/01, Faculty of Business and Economics, Monash University, Melbourne.

Barnes, Allison. (2001). "Low Fertility: A Discussion Paper," Occasional paper number 2, Department of Family and Community Services, Canberra.

Barnett, Rosalind, and Rivers, Caryl. (1998). He Works/She Works: How Two Income Families are Happy, Healthy, and Thriving. Cambridge MA: Harvard University Press.

Benet, Siobhan. (2001). "Parents May Pay Ultimate Price for Low-Cost Care," Women's E News, June 21 [online at: www.womensenews.org]. 
Bittman, Michael (1999). "Parenthood Without Penalty: Time Use and Public Policy in Australia and Finland," Feminist Economics, 5(3), 27-42.

Bond, James T., Galinsky, Ellen, and Swanberg, Jennifer. (1998). The 1997 National Study of the Changing Workforce. New York: Families and Work Institute.

Budig, Michelle J. and England, Paula. (2001). "The Wage Penalty for Motherhood," American Sociological Review, 66(2), 204-225.

Burkett, Eleanor. (2000). The Baby Boon: How Family-Friendly America Cheats the Childless. New York: Free Press.

Bushey, Heather, and Gunderson, Bethney. (2001). "Hardships Suffered by Welfare Families," Report for the Economic Policy Institute, Washington DC, June 27 [online at: www.epinet.org].

Centrelink (2002), online at: www.centrelink.gov.au

Chapman, Bruce, Dunlop, Yvonne, Gray, Matthew, Liu, Amy and Mitchell, Deborah (2001) "The Impact of Children on the Lifetime Earnings of Australian Women: Evidence from the 1990s," Working paper, Australian National University.

Crittenden, Ann. (2001). The Price of Motherhood. New York: Metropolitan Books.

Davis, Edward and Lansbury, Russell (2000). "Employment Relations in Australia," in G. Bamber and R. Lansbury (eds.), International and Comparative Employment Relations, London: Sage Publication, pp. 110-143.

Deutsch, Francine. (1999). Halving It All: How Equally Shared Parenting Works. Cambridge MA: Harvard University Press.

DEWRSB, Department of Employment, Workplace Relations and Small Business. (1999). Work and Family: State of Play 1998, Canberra.

Dowd, Nancy. (2000). Redefining Fatherhood. New York: New York University Press.

Drago, Robert. (2000). “Trends in Working Time in the U.S.: A Policy Perspective," Labor Law Journal, 51(Winter), 212-218. 
. Costanza, David, Caplan, Robert, Brubaker, Tanya, Cloud, Darnell, Harris, Naomi, Kashian, Russell, and Riggs, T. Lynn. (forthcoming, 2001). "The Willingness-to-pay for Work/Family Policies: A Study of Teachers," Industrial and Labor Relations Review.

Dickert-Conlin, S. and S. Houser (1999), "EITC, AFDC and the Female Headship Decision," Institute for Research on Poverty Working Paper No. 1192-99.

Duncan, Alan, and Harris, Mark. (2001). "Simulating the Behavioural Effects of Welfare Reforms among Sole Parents in Australia," Working Paper no. 6/01, Melbourne Institute of Applied Economic and Social Research, June.

Folbre, Nancy. (2001). The Invisible Heart: Economics and Family Values. New York: New Press.

Fried, Mindy. (1998). Taking Time: Parental Leave Policy and Corporate Culture. Philadelphia PA: Temple University Press.

Fukuyama, Francis. (1999). The Great Disruption: Human Nature and the Reconsitution of Social Order. New York: Free Press.

Garey, Alita Ilta. (1999). Weaving Work and Motherhood. Philadelphia PA: Temple University Press.

Gerstel, Naomi, and Clawson, Dan. (2000). "Unions Responses to Family Concerns," Working Paper, Department of Sociology, U.Mass./Amherst.

Glass, Jennifer. (2000). "Envisioning the Integration of Family and Work: Toward a Kinder, Gentler Workplace," Contemporary Sociology, January,129-143.

Glezer, Helen, and Wolcott, Ilene. (2000). "Conflicting Commitments: Working Mothers and Fathers in Australia," in L.L. Haas, P. Hwang, and G. Russell (eds.), Organizational Change and Gender Equity, London: Sage, 43-56.

Harrington, Mona. (1999). Care and Equality: Inventing a New Family Politics. New York: Knopf.

Haveman, R. and B. Wolfe (2001), “The 1996 U.S. Welfare Reform: Objectives, Effects and Lessons", Paper presented at Melbourne Institute Labour Economics Seminar Program. 
Heymann, Jody. (2000). The Widening Gap: Why America's Working Families Are in Jeopardy - and What Can Be Done About It. New York: Free Press.

Hochschild, Arlie, with Anne Machung. (1989) The Second Shift. New York: Avon. . (1997). The Time Bind: When Work Becomes Home \& Home Becomes Work. New York: Metropolitan Books.

Hotz, J. and J. Scholz (2001), "The Earned Income Tax Credit", National Bureau of Economic Research, Working Paper 8078.

Joint Governments' Submission (2000). Safety Net Review-Wages: 1999-2000, Commonwealth Department of Employment, Workplace Relations and Small Business, Canberra.

Kalb, Guyonne. (1999). "Labour Supply and Welfare Participation in Australian Two-Adult Households: Comparing 1986/87 with 1994/95," Working Paper no. BP-34, Centre of Policy Studies, Monash University, December.

. (2000). "Labour Supply and Welfare Participation in Australian Two-Adult Households: Accounting for Involuntary Unemployment and the 'Cost' of Part-time Work," Preliminary Working Paper no. BP-35, Centre of Policy Studies, Monash University, October.

Lakoff, George. (1996). Moral Politics: What Conservatives Know that Liberals Don't. Chicago IL: University of Chicago Press.

Maushart, Susan. (2001). Wifework: What Marriage Really Means for Women. Melbourne: Text Publishing.

McClure, Patrick. (2000). "Participation Support for a More Equitable Society.” Final Report of the Reference Group on Welfare Reform, Department of Family and Community Services, Canberra.

McDonald, Peter. (2000). "Gender Equity, Social Institutions and the Future of Fertility," Journal of Population Research, 17(1), 1-16. 
Moen, Phyllis, and Yu, Yan. (2000). "Effective Work/Life Strategies," Social Problems, (August), 291-326.

Perry-Jenkins, Maureen, Repetti, Rena L., and Crouter, Ann C. (2000). "Work and Family in the 1990s," Journal of Marriage and the Family, 62, 981-998.

Risman, Barbara. (1998). Gender Vertigo: American Families in Transition. New Haven CT: Yale University Press.

Robinson, John P. and Godbey, Geoffrey. (1997). Time for Life: The Surprising Ways Americans Use Their Time. University Park PA: Pennsylvania State University Press.

Russell, Graeme, and Bowman, Lyndy. (2000). "Work and Family: Current Thinking, Research and Practice," Report for the Department of Family and Community Services, Canberra.

Sandberg, John and Hofferth, Sandra. (2001). "Changes in Children's Time with Parents, U.S., 1981-1997," PSC Research Report no. 01-475, University of Michigan, May. [available on-line http://www.psc.isr.umich.edu/pubs/papers/rr01-475.pdf ]

Schor, Juliet B. (1998). The Overspent American: Upscaling, Downshifting, and the New Consumer. New York: Basic Books.

Stone, Deborah. (2000)."Why We Need a Care Movement," The Nation, March 13.

UMR Research Party Ltd. (2001). “Australia-wide Study of Workplace Issues,” Report for the Australian Council of Trade Unions, February.

U.S. Census Bureau for the Bureau of Labor Statistics (2000a). Current Population News Releases, USDL 00-333, Work Experience in the Population 1999. Available [on-line]: $\mathrm{ftp}: / / 146.142 .4 .23 /$ pub/news.release/work.txt

U.S. Census Bureau for the Bureau of Labor Statistics (2000b). Current Population News Releases, USDL 01-21, Union Members in 2000. Available [on-line]: ftp://146.142.4.23/pub/news.release/union2.txt

U.S. Department of Labor (1999). Report on the American Workforce, Available [on-line]: http://www.bls.gov/opub/rtaw/pdf/rtaw1999.pdf 
Varner, Amy and Drago, Robert. (2001). "Fertility and Work in the United States: A Policy Perspective," Report for the National Institute of Population and Social Security Research, Japan.

Waldfogel, Jane. (1998). 'Understanding the 'Family Gap' in Pay for Women with Children," Journal of Economic Perspectives, 12(1), 137-156.

Whyte, William H., Jr. (1956). The Organization Man. New York: Simon \& Schuster.

Williams, Joan. (1999). Unbending Gender: Why Work and Family Conflict and What to Do About It. New York: Oxford University Press.

Willis, Judith S. (1997). "Women and Part-time Employment: The Waverley Survey," General Paper No. G122, Centre of Policy Studies, Monash University, December.

Wolfe, B. (2000), "Incentives, Challenges and Dilemmas of TANF", Institute for Research on Poverty, Discussion Paper No. 1209-00.

Wooden, Mark. (2000). The Transformation of Australian Industrial Relations. Sydney: The Federation Press.

. (2001). “Are Non-standard Jobs Sub-standard Jobs?” Australian Social Monitor, $3(3), 65-70$.

.(forthcoming). "Industrial Relations Reform in Australia: Causes, Consequences and Prospects," Australian Economic Review.

Zedlewski, S, P. Holcomb and A.E. Duke (1998), "Cash Assistance in Transition: The Story of 13 States", Assessing the New Federalism Occasional Paper 16, Urban Institute, Washington, DC. 


\section{Appendix: Financial incentives through the tax and social security system for individuals with children to enter the workforce}

Alongside efforts made by organisations to make workplaces more family friendly, the structure of tax and social security systems also places additional incentives (or disincentives) on individuals with children to enter the workforce. In this appendix we summarise the main benefits available to families with children in Australia and the United States, both through the tax system and through the social security system. We also try to generate a picture of incentives faced by typical family types when interacting the effects of direct tax and social security systems. This is much more difficult to do in the case of the United States as taxes and benefits vary across the States.

\section{Australia \\ Basic Social Security Payments ${ }^{2}$}

When individuals are out of work, or are employed and receive low incomes in Australia, the social security system provides a safety net. Typically in a couple household with dependents, the household head will, subject to a means test, be eligible for some kind of unemployment benefit, either Newstart Allowance or Youth Allowance, where the individual must satisfy an activity test which requires you to be willing and able to undertake any suitable work. The partner may be eligible for Parenting Payment (partnered) and a range of Family Payments. In a single parent household the parent may be eligible to Parenting Payment (single) and a range of Family Payments. Rent assistance is also available to eligible private renters. Below is a description of the social security payments specifically available to families with children.

\section{Parenting Payment}

To qualify for Parenting Payment a person must have primary care of a child under 16 years of age, have income and assets under certain amounts; and meet residence requirements.

\footnotetext{
${ }^{2}$ The information from this section has been edited from the payment details outlined on the Centrelink web site: www.centrelink.gov.au and reflect the arrangements of the Australian social security system at March 2002.
} 
The maximum rate of Parenting Payment (Partnered) is up to $\$ 332.80$ per fortnight (or up to $\$ 399.00$ per fortnight if illness separated, respite care couple or partner in gaol). An education entry payment of $\$ 208$ may be payable. The maximum rate of Parenting Payment (Single) is up to $\$ 421.80$ per fortnight. A Pharmaceutical Allowance of $\$ 5.80$ per fortnight is also payable. An Education Entry Payment of \$208 or an Employment Entry Payment of \$104 may also be payable. If you are studying, a Pensioner Education Supplement may be payable.

The income test for single parents is as follows. The payment is withdrawn at 40 cents in the dollar for each dollar of income earned above $\$ 136.60$ for one child, plus add $\$ 24.60$ to the threshold per additional child.

The income test for partnered parents differs depending on whether their partner is a pensioner or not. If their partner is not a pensioner the customer's income reduces their payment by 50 cents for each dollar between $\$ 62$ and $\$ 245$, and by 70 cents for each dollar above \$245, per fortnight. Partner's income up to \$561per fortnight has no effect. Partner's income over this limit reduces the rate by 70 cents for each extra dollar. Thus, for maximum payment the customer's income must be no more than $\$ 62$ per fortnight AND the partner's income must be no more than $\$ 561$ per fortnight. Different limits apply if the partner receives Youth Allowance or Austudy payment.

If their partner is a pensioner the couple's combined income reduces rate by 25 cents for each dollar between $\$ 124$ and $\$ 490$, and by 35 cents for each dollar above $\$ 490$, per fortnight. For maximum payment the couple's combined income must be no more than $\$ 124$ per fortnight. For part payment the couple's combined income must be less than $\$ 1,179.42$ per fortnight.

Parenting Payment is also subject to an assets test.

Proposals to impose additional requirements on recipients of Parenting Payment under the "Australians Working Together" banner were introduced in the latest Commonwealth Budget (2001/2002). The proposals included imposing requirements on recipients of Parenting Payment with children thirteen years and over to undertake an average of six hours a week of activities designed to help them return to work. For recipients with children aged over six years it was proposed to impose a requirement to attend an annual interview to help prepare 
them for re-entry into the labour force in the long term. However, as of writing these changes have not yet been passed through the Senate.

\section{Family Payments}

\section{Family Tax Benefit Part A}

You may qualify for Family Tax Benefit Part A if you have dependent children under 16 and meet residence requirements. You can also receive Family Tax Benefit Part A for a dependent if the dependent is aged between 16 and 20 years; or aged between 21 and 24 years and undertaking full-time study, and in your care, and an Australian resident or living with you and you are an Australian resident.

You cannot receive Family Tax Benefit for a dependent who is aged between 5 and 15 years, not undertaking full-time study and has a taxable income of $\$ 8,078$ or more; or any age and receiving a social security pension or benefit or a payment under a labour market program; or your partner; or aged 16 or over and has taxable income of $\$ 8,078$ or more.

\section{Maximum Rate of Family Tax Benefit A:}

$\begin{array}{lrc}\text { For each child } & \text { Per fortnight } & \text { Per Year } \\ \text { Under 13 years } & \$ 122.92 & \$ 3,204.70 \\ 13-15 \text { years } & \$ 155.82 & \$ 4,062.45 \\ 16-17 \text { years } & \$ 39.48 & \$ 1,029.30 \\ 18-24 \text { years } & \$ 53.06 & \$ 1,383.35\end{array}$

In an approved care organisation

$0-24$ years $\$ 39.48 \quad \$ 1,029.30$

\section{Base Rate of Family Tax Benefit:}

$\begin{array}{lcc}\text { For each child } & \text { Per fortnight } & \text { Per Year } \\ \text { Under 18 years } & \$ 39.48 & \$ 1,029.30 \\ 18-24 \text { years } & \$ 53.06 & \$ 1,383.35\end{array}$

A large family supplement of $\$ 8.40$ per fortnight for the fourth and each subsequent child may also be payable. Also a Multiple Birth Allowance may also be payable. This is a fortnightly payment of $\$ 102.76$ for triplets and $\$ 137.20$ for multiple births of quadruplets or 
more. Family Tax Benefit A customers who receive more than the base rate and pay rent privately may also be paid Rent Assistance.

Income Test for Family Tax Benefit Part A

For Family Tax Benefit Part A, if your family's taxable income for this financial year is $\$ 29,857$ or less, your payment will not be affected by the income test.

If your taxable income is more than $\$ 29,857$ for this financial year, your payment will reduce by 30 cents for each dollar above $\$ 29,857$, until your payment reaches the base rate of Family Tax Benefit Part A.

The base rate of Family Tax Benefit Part A is available until your taxable income reaches $\$ 77,234$ a year (plus $\$ 3,139$ for each Family Tax Benefit child after the first). Family Tax Benefit Part A will reduce by 30 cents for every dollar over that amount until your payment reaches nil.

If you get more than the base rate of Family Tax Benefit A, a maintenance income test may also apply.

\section{Family Tax Benefit Part B}

FTB(B) is designed to provide assistance to single income earner families. You qualify for Family Tax Benefit Part B if you have dependent children under 16 and you meet residence requirements. You can also qualify for Family Tax Benefit Part B if your youngest qualifying child is dependent on you, aged between 16 and 18 years and undertaking full-time study.

You cannot receive Family Tax Benefit for a dependant who is aged between 5 and 15 years, not undertaking full-time study and has a taxable income of $\$ 7,663$ or more; or any age and receiving a social security pension or benefit or a payment under a labour market program; or your partner; or aged 16 or over and has taxable income of $\$ 7,663$ or more.

The primary earner in a partnered relationship and sole parents are not subject to an income test. 


\section{Maximum Rate of Family Tax Benefit B}

Age of Youngest Child

Under 5 years

5-15 years
Per fortnight

$\$ 105.56$

$\$ 73.64$
Per Year

$\$ 2,752.10$

$\$ 1,919.90$

(or 16-18 years if a full-time student)

If you are the secondary earner in a partnered relationship, you can earn up to $\$ 1,679$ each year before it affects your Family Tax Payment Part B. Payments are reduced by 30 cents for each dollar of income earned over $\$ 1,679$.

\section{Child Care Benefit}

If you use approved or registered child care and pay child care fees, you may be able to get Child Care Benefit if your child or children born on or after 1 January 1996 have age appropriate immunisation, are on a catch-up schedule, or have an exemption; or a Commonwealth-Government sponsored student; and you meet residence requirements.

You (and your partner if you have a partner) must be working, studying or training to receive any Child Care Benefit for registered care or Child Care Benefit for more than 20 hours a week of approved care.

Approved Child Care services includes most long day care, family day care, outside school hours day care, vacation care, some occasional care services and some in-home care.

Child Care Benefit for Approved Care is up to $\$ 129$ per week for non-school age child in 50 hours of care. A minimum of $\$ 21.70$ for incomes over an upper threshold is available. Rates for school children are 85 per cent of the non-school age rate.

Child Care Benefit is subject to an Income Test if you use Approved Care. Registered Care is not subject to an income test. This income test is effective from 20 March 2002. 
The maximum rate is payable for families with incomes under $\$ 29,857$ or families on an income support payment.

The minimum rate is payable over the following thresholds:

Number of children in care 1 2 $3+$
Upper income threshold $\$ 85653$ $\$ 92,904$ $\$ 105,554+\$ 17,618$ for each child after the third

\section{Maternity Allowance}

You qualify for Maternity Allowance if you have a new baby; or you adopt a baby under 26 weeks of age and claim within 13 weeks; and you qualify for Family Tax Benefit A within 13 weeks of the baby's birth or adoption; and meet residence requirements.

Maternity Allowance is paid as a non-taxable lump sum payment of $\$ 798.72$ per child. It is usually paid with the first instalment of Family Tax Benefit for the baby, where Family Tax Benefit is paid fortnightly and not through the tax system.

For multiple births, maternity allowance is paid for each child.

This payment is subject to an income test such as that for Family Tax Benefit Part A.

\section{Maternity Immunisation Allowance}

Maternity Immunisation Allowance is paid for children born on or after 1 January 1998, after the child reaches 18 months old and either has been fully immunised, or is exempt from immunisation. A non-taxable lump sum payment of $\$ 208$ is paid with the families Family Tax Benefit. The payment is subject to an income test such as that for Family Tax Benefit Part A. 


\section{Double Orphan Pension}

Double Orphan Pension is paid at a rate of $\$ 42.80$ per fortnight. It is usually paid on top of Family Tax Benefit. You qualify for Double Orphan Pension if you are the carer of a double orphan under 16 years of age (or a full-time student aged 16-21 years who does not receive Youth Allowance); and are eligible for Family Tax Benefit; and meet residence requirements.

Carer Allowance (child) (previously known as Child Disability Allowance)

A person may receive Carer Allowance (Child) if they look after a child with a disability or severe medical condition who requires a lot of additional care or attention in their own home. Both the carer and the child with a disability must also meet residence requirements. Carer Allowance is a non-taxable payment of $\$ 85.30$ per fortnight.

Taxes, the Medicare levy and rebates

There are also other financial incentives for families to have children, operating through the tax system. The Medicare levy of $1.5 \%$ is shaded-in at higher income levels for families with children. The $1 \%$ surcharge is also payable at higher income levels for families with children. Also rebates are available to all individuals on low incomes with additional rebates available to all pensioners and beneficiaries.

Also note that in Australia, tax returns are filed for each individual based on individual income.

Interactions of tax and social security

Single parents

The financial incentives faced by a hypothetical sole parent with 1 child under 5 years and two children between 5 and 12 years are presented in Figure A1 with net incomes shown in part (a) of the diagram and effective marginal tax rates in part (b). Child Care Benefit is not included in this schedule of net incomes as information on hours of childcare use is not available. This mother faces a wage of $\$ 20$ an hour and pays $\$ 200$ per week in rent. 
Figure A1a: Net income by hours of work, sole parent household

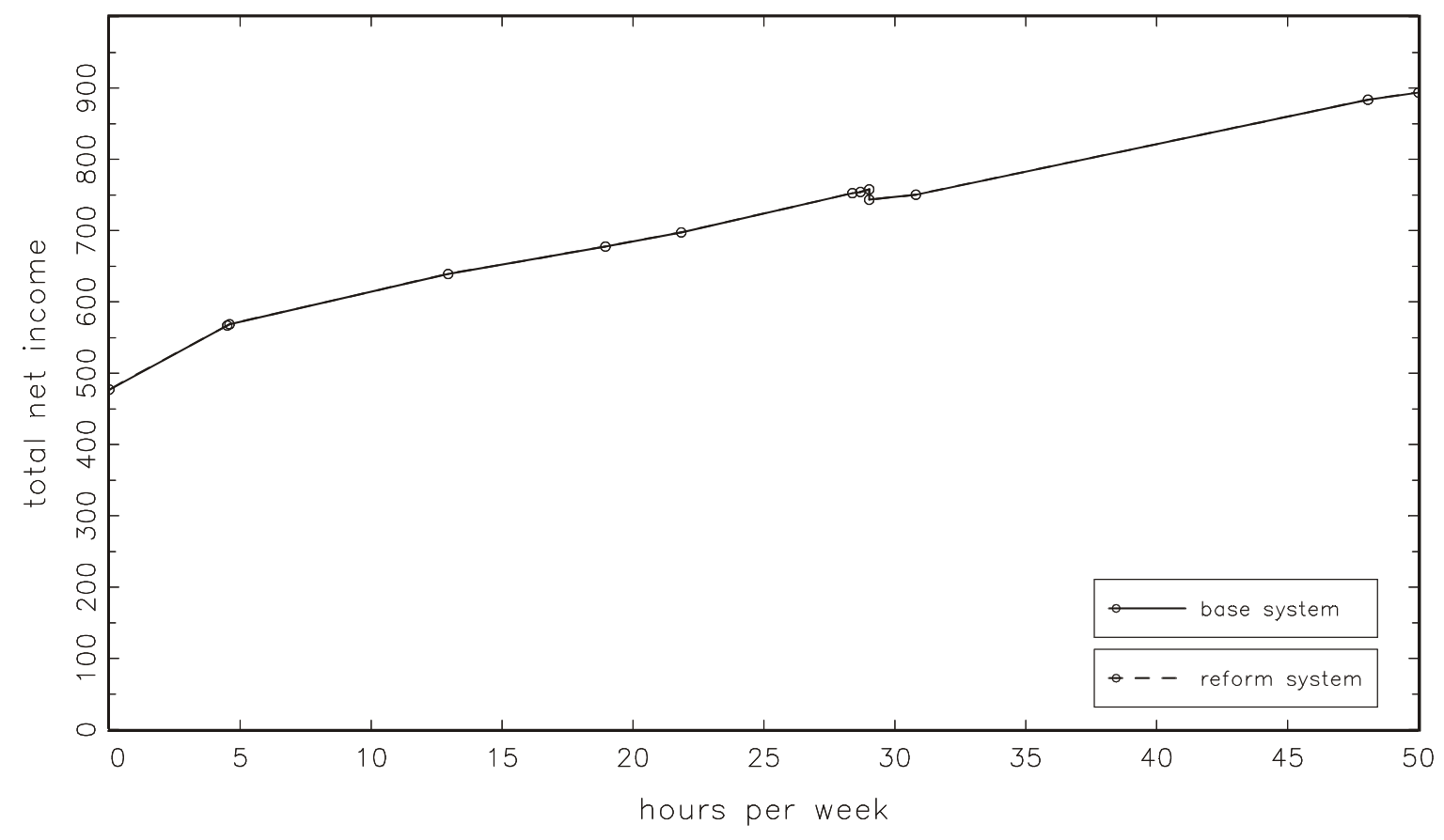

Figure A1b: Effective marginal tax rates by hours of work, sole parent household

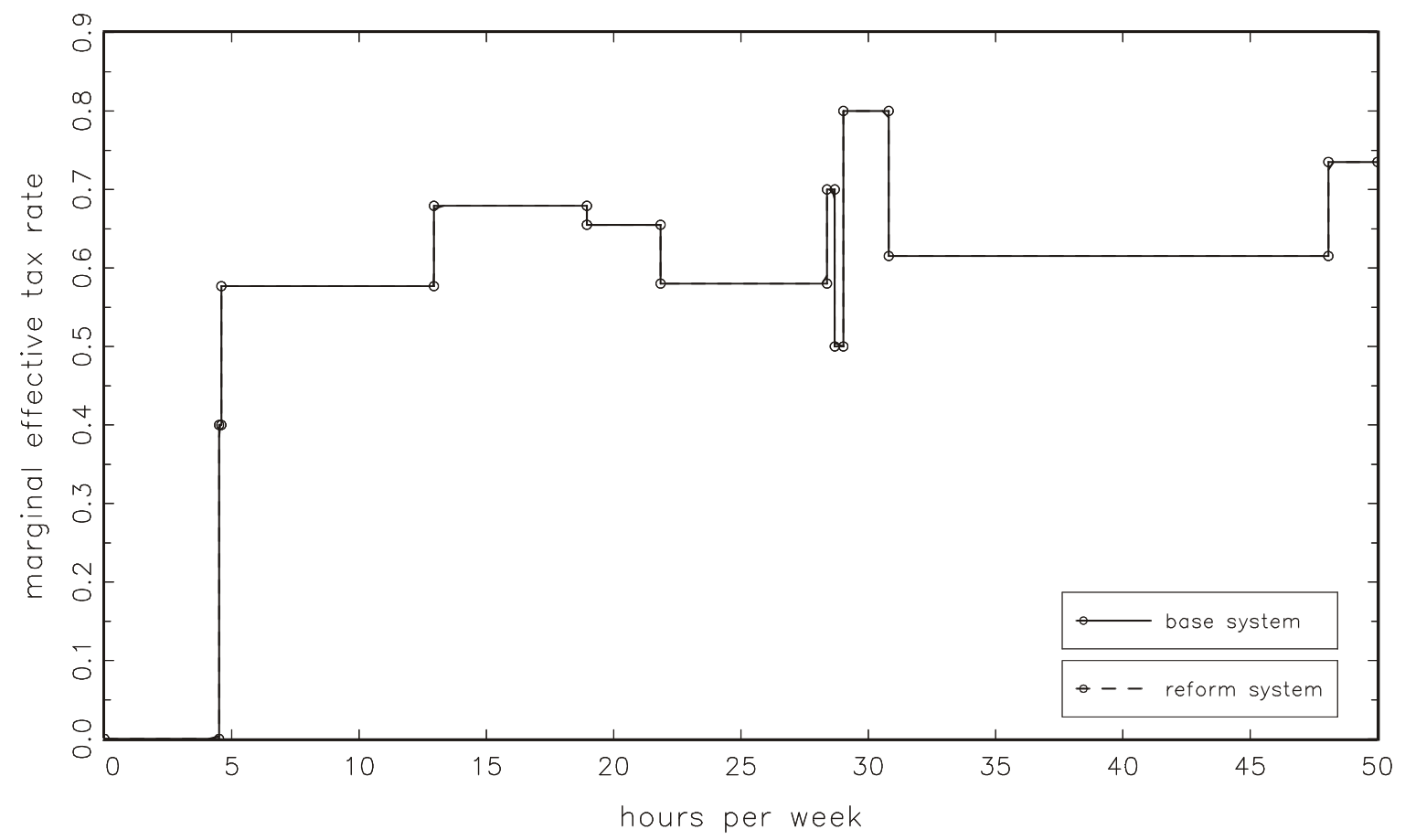

Note that the above tables assume an hourly wage of \$20. 
Couple with dependents

In the following, our hypothetical household consists of a couple with 1 child aged 0 to 2 years, paying rent of $\$ 200$ per week. This family is initially entitled to maternity allowance.

Figures A2a and A2b present the net household income and EMTR schedules respectively for our hypothetical household associated with varying the hours of work of the spouse given that her husband is working full-time with a gross income of $\$ 600$ a week. The spouse's offered wage is $\$ 25$ an hour.

Figure A2a: Net income by hours of work of spouse, couple with dependents, reference person working 40 hours a week

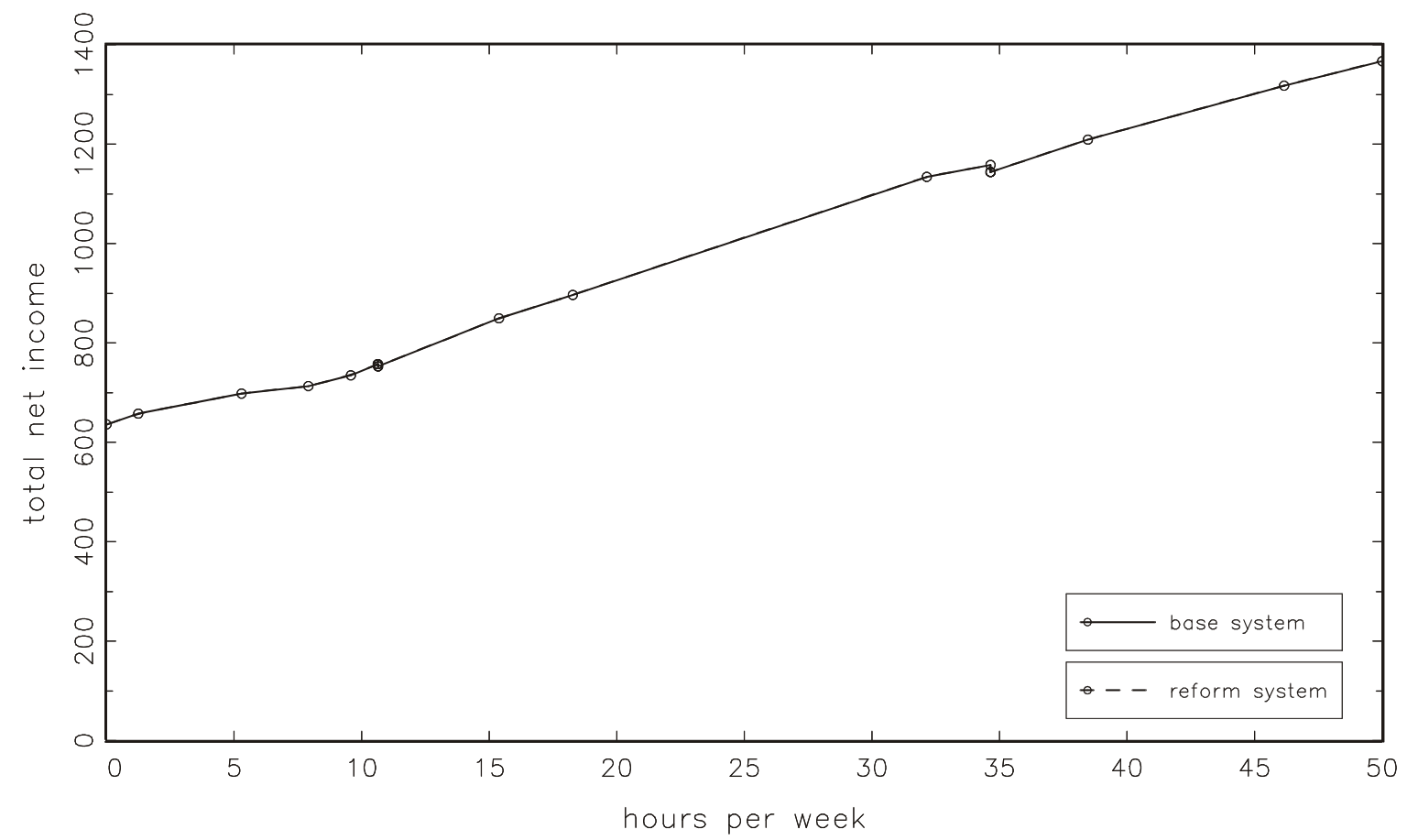


Figure A2b: Effective marginal tax rates by hours of work of spouse, couple with dependents, reference person working full-time

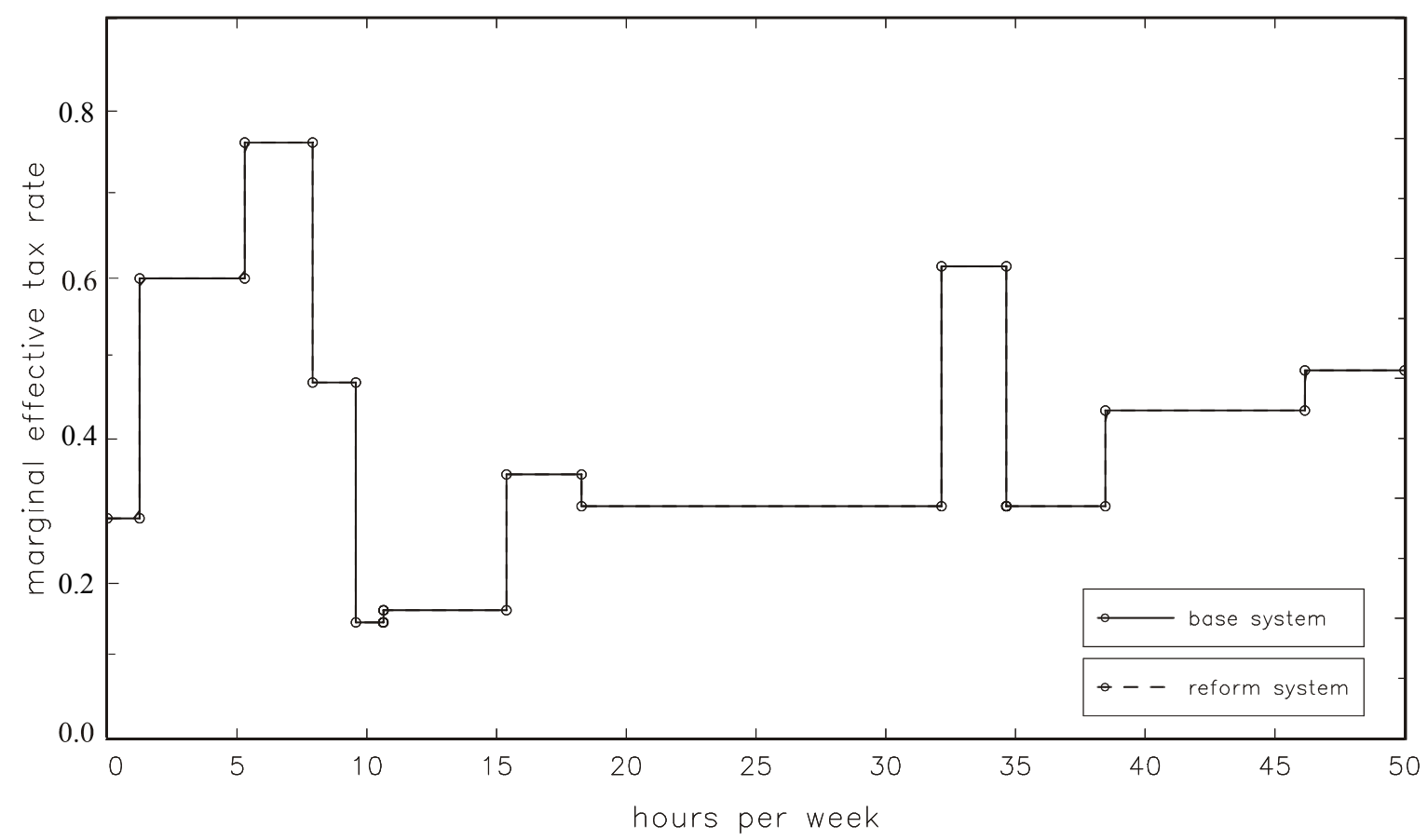

Note that the above diagrams assume an hourly wage of $\$ 15$ for the reference person and $\$ 25$ for the spouse.

We now turn to the case where the husband is not working. Figures A3a and A3b show net incomes and EMTR schedules for the same hypothetical household as above however in this scenario we examine the effect on household incomes over the range of spouse's hours when her husband is not working. As in the previous example, the spouse's offered wage is $\$ 25$ an hour. 
Figure A3a: Net income by hours of work of spouse, couple with dependents, reference person not working

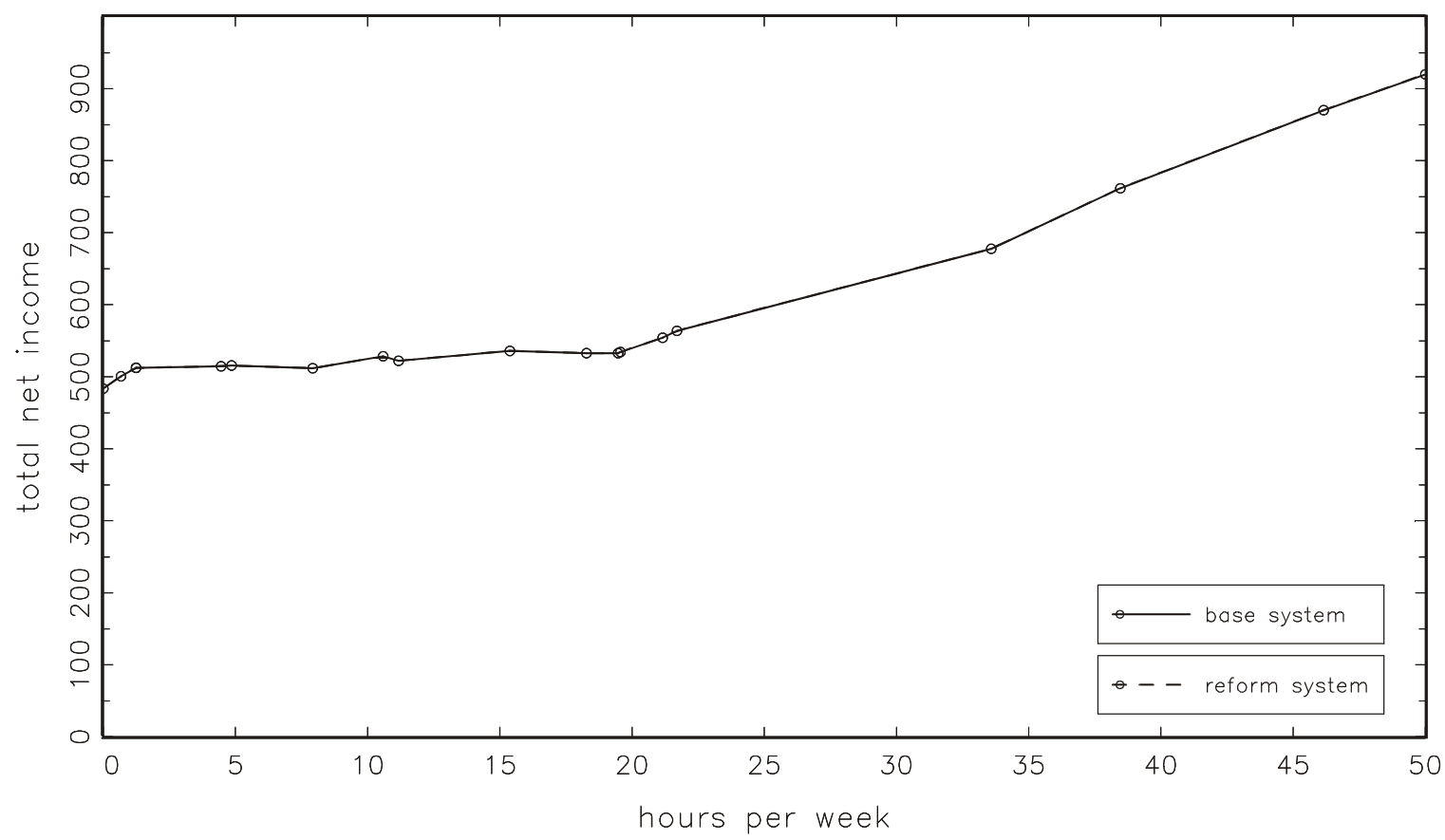

Figure A3b: Effective marginal tax rates by hours of work of spouse, couple with dependents, reference person not working

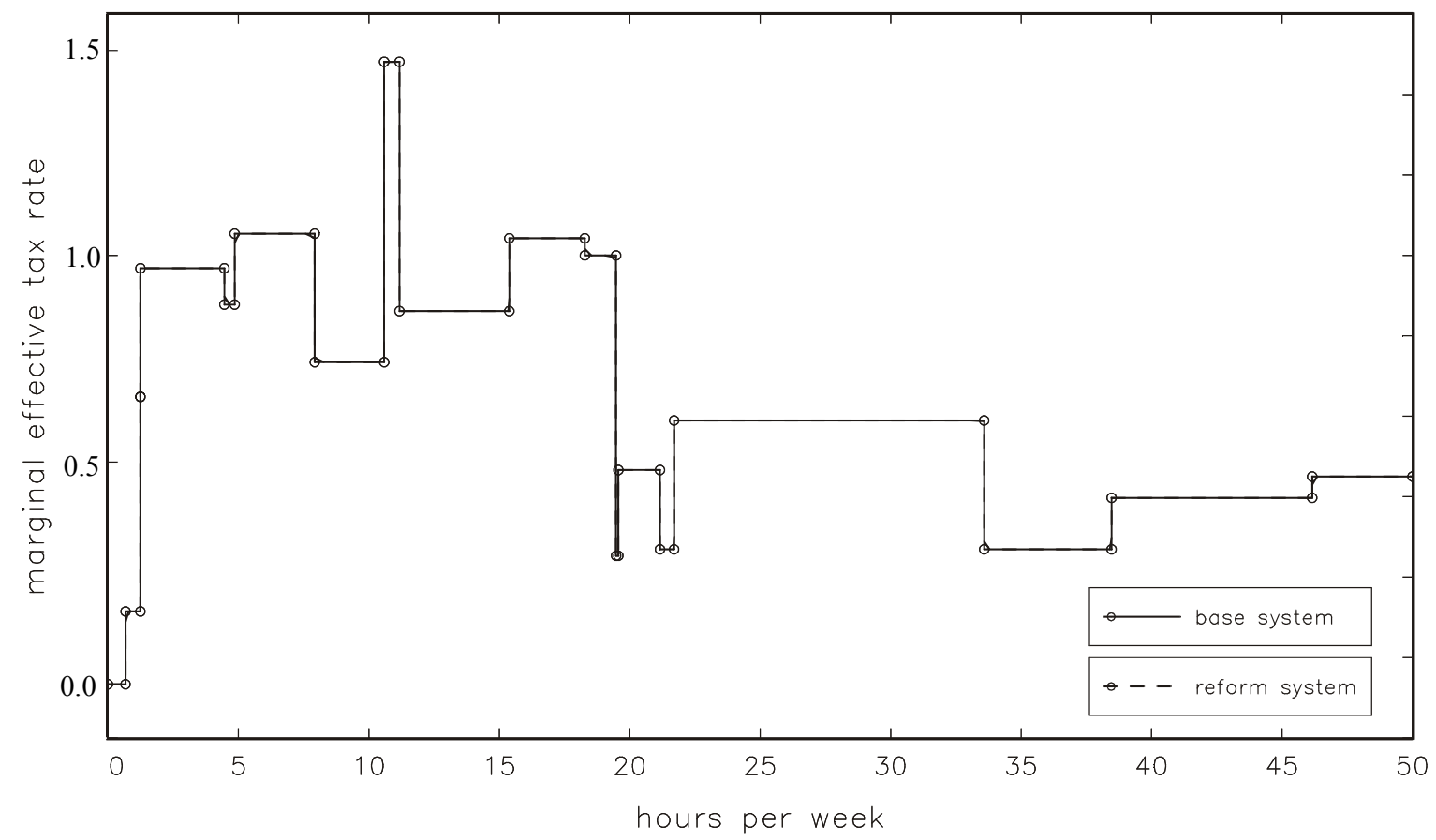

Note that the above diagrams assume an hourly wage of $\$ 25$ for the spouse. 


\section{The United States}

Interactions between the tax and social security system in the U.S. are not as transparent as in Australia. This is mainly due to there being differing income tax and social security schedules both at the Federal level and at the State level. The following does its best to try and summarise the incentives faced by a typical family in the U.S.

Income tax in the U.S. can be filed individually or jointly based on either individual incomes or combined income. Income taxes are payable both at the Federal and in most cases also at the State level. As of July 2000 there were deductions of $\$ 2,800$ for each dependent child. Along with these deductions there are other varying forms of assistance for children through the tax system. A summary of these follows:

\section{Child and Dependent Care Credit}

Families in the US may also be eligible to claim the Child and Dependent Care Credit. The credit may be claimed for expenses incurred for the care of a dependent child under 13 years or a disabled dependent or spouse while working or searching for work. The Credit can be up to 30 per cent of expenses.

\section{Child Tax Credit}

A Child Tax Credit of up to $\$ 500$ can be claimed per qualifying child. A qualifying child is a child who is claimed as your dependent, is under 17 years of age, and is a US citizen or resident. The credit is withdrawn at certain income levels which depend on a families filing status. If married and filing jointly, the credit is withdrawn at an income level of $\$ 110,000$. If the head of household, single, or qualifying widow/er it is withdrawn at $\$ 75,000$. While if married filing separately it is withdrawn at $\$ 55,000$. The child tax credit is also limited by the amount of your tax liability. However, you may be able to claim the "additional" child tax credit if you have three or more qualifying children and you are not able to claim the full $\$ 500$ child tax credit for each child. The additional child tax credit is a refundable credit i.e. it may give you a refund even if you do not owe tax. 
The total of both credits cannot be more than $\$ 500$ for each qualifying child. These credits are in addition to the child and dependent care credit and the earned income tax credit.

\section{Dependent Care Assistance program}

The value of benefits provided by the employer may be excluded from the employees wages if it is believed that the employee can exclude these benefits from their gross income. The employee can then generally exclude up to $\$ 5000$ of benefits received from gross income each year (or $\$ 2500$ for married couples filing separate returns).

\section{TANF}

In August 1996 the Temporary Assistance for Needy Families (TANF) program was passed in the US. TANF replaced the Aid to Families with Dependent Children (AFDC) program. AFDC provided cash assistance to poor families with children headed by a single parent or guardian. The TANF program provided the states to deliver hand-tailored individual programs where the responsibilities imposed on the states are to enforce work-often full-time, year-round work by poor, often single parent families. Also imposed on the states was the requirement to impose rules that eliminate the provision of income support to any nonelderly, non-disabled family after a total of five years of help has been received.

The approach taken by the states since the induction of the TANF program have been diverse. Some of the responses outlined in Havemen and Wolfe (2001) include:

- Providing “diversion" payments to keep families from seeking welfare payments;

- Enabling families to keep a larger share of their earnings without reducing benefits;

- Imposing restrictions on which families will not be subject to work requirements;

- Setting a time when full work requirements-implying severance of cash support-will be imposed;

- Providing subsidies for child care when working;

- Subsidising or providing health insurance;

- Creating public service jobs; 
- Changing the delivery of services to clients from case-oriented and fractured programs to 'one stop centres' with advice, training and counselling;

- Imposing sanctions (eg. Cutting or eliminating cash support) on families which fail to meet program requirements; and

- Changing the generosity of cash benefits that are paid.

"State policy choices since TANF are increasing diversity in cash assistance policies across the nation. Some states are moving further toward policies that discourage the use of welfare, while others are maintaining large parts of the safety net that were available under approaches to reach this goal." Zedlewski, Holcomb and Duke (1998).

\section{Food Stamp program}

Poor families are eligible for a food stamp voucher depending on their level of income.

\section{Medicaid}

Prior to the TANF reforms, Medicaid provided health care benefits to poor children (even those in two parent families), single mothers who receive AFDC benefits and pregnant women. The eligibility link between Medicaid and receipt of cash assistance for families was terminated in the 1996 reforms. Under the new eligibility category, at a minimum, states must provide Medicaid to children and parents whose income and resources are below the state's AFDC income and resource standards, and who meet AFDC family composition requirements as they were in effect in July 1996.

Medicaid is also available to pregnant women and children in families with income substantially above a state's July 1996 income standard under the so-called Medicaid "poverty level" categories. Under federal law, pregnant women and children below age six in families with incomes up to 133 percent of the federal poverty line are eligible for Medicaid, as are children age six through 14 in families with incomes up to 100 percent of the federal poverty line. States can expand Medicaid beyond these federal minimum requirements. For example, as of October 1998, some 44 states and the District of Columbia had expanded coverage for children beyond the federal minimum requirements. Some states have extended 
Medicaid coverage to all children in families with incomes well above the federal poverty line.

While states are required to place a time limit on TANF assistance, they may not impose a time limit on Medicaid assistance.

\section{Earned Income Tax Credit}

Available to all low-income working taxpayers, but is targeted on those with dependent children. The Earned Income Tax Credit is payable through the Federal Income tax system. The benefit is a tax credit, which is refunded to the family if its level exceeds their tax liability. The EITC creates incentive for one person in a family to enter employment, however it leads to what is known as a "marriage penalty". Two working single parents living in the same household would receive a much larger credit than a two earner couple with the same number of children as the credit is based on family income.

In 1999, taxpayers with two or more children could receive a credit of forty per cent of income up to $\$ 9,450$, for a maximum credit of $\$ 3,816$. Taxpayers with two or more children with earnings between $\$ 9,540$ and $\$ 12,460$ receive the maximum credit. Their credit is reduced by 21.06 per cent of earnings between $\$ 12,460$ and $\$ 30,585$. Figure A4 shows the Federal EITC parameters in 1999 for families with no children, one child and two children. 
Figure A4: Federal EITC parameters, 1999

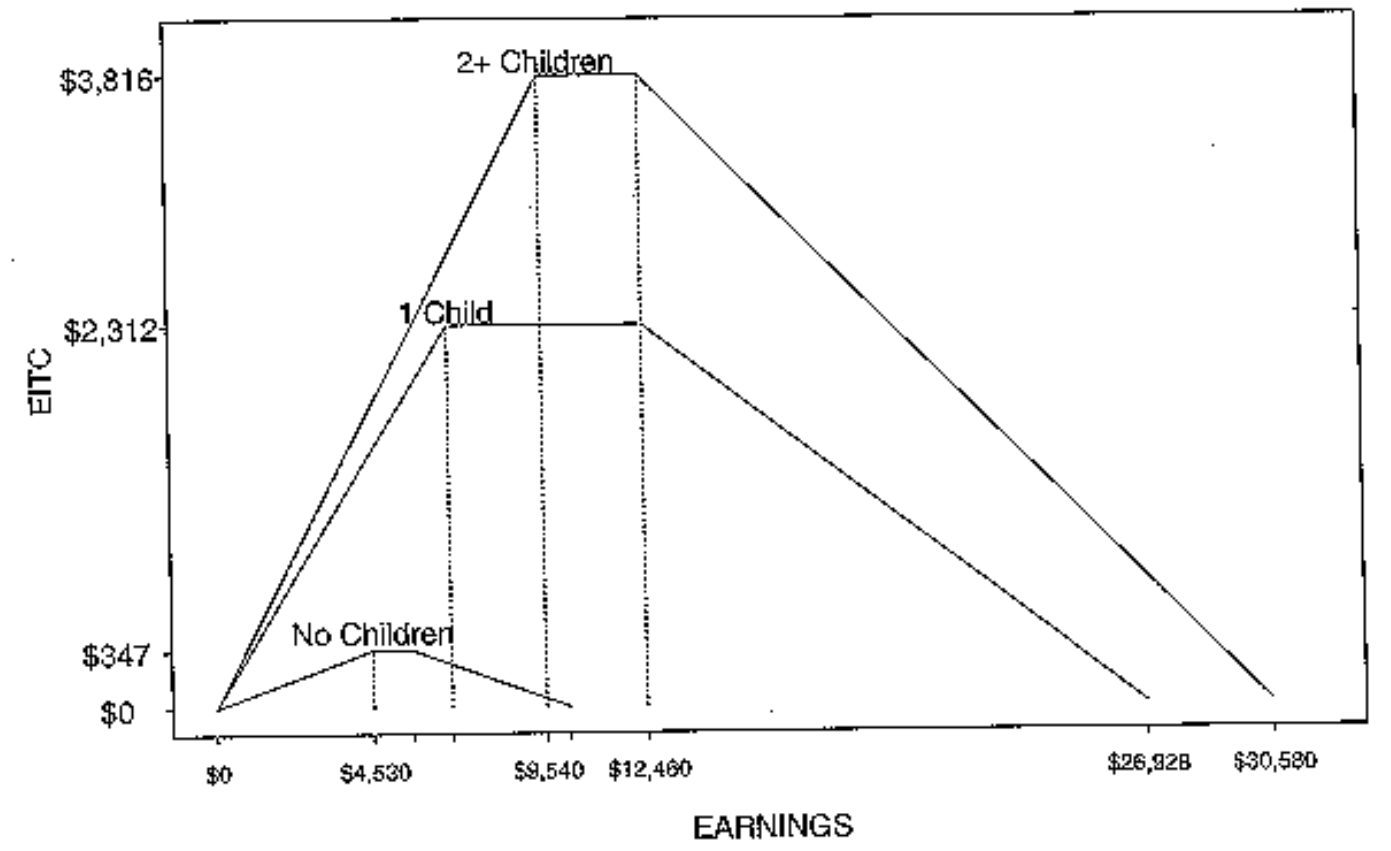

Source: Dickert-Conlin and Houser, 1999.

The EITC is not only part of the Federal tax system. As of July 2000, fourteen US states and the District of Colombia have EITC's as part of their state income taxes. Table 1 provides some detail on the levels of the tax credit across states.

As the range of benefits available to families across the US states is incredibly varied it is not possible in this analysis to provide comparable net income and effective marginal tax rate schedules for hypothetical family types in the nation. Thus we will focus on the incentives faced by single parent families in Wisconsin, which adopted one of the most radical policy changes since the TANF program. A schedule of net incomes is presented for a single parent household with two dependents in Figure A5. We also look at the net incomes and marginal tax rates of a couple with two dependents in Illinois (see Figure A6). Note that for this family type the incentives faced are not completely provided by the diagram as only taxes are taken into consideration and not benefits. 
Table 1: State earned income tax credits, 2000

\begin{tabular}{|c|c|c|}
\hline & State & $\begin{array}{l}\text { Percentage of Federal } \\
\text { Credit }\end{array}$ \\
\hline \multirow[t]{12}{*}{ Refundable credits } & Colorado & 10 \\
\hline & District of Columbia & 10 \\
\hline & Kansas & 10 \\
\hline & Maryland & 10 \\
\hline & Massachusetts & $10(15 \%$ in 2001$)$ \\
\hline & Minnesota $^{1}$ & $\begin{array}{l}\text { Averages } 34 \% \text { varies by } \\
\text { earnings }\end{array}$ \\
\hline & New Jersey & $\begin{array}{l}10(20 \% \text { by } 2003) \text {, limited } \\
\text { to families with incomes } \\
\text { below } \$ 20,000\end{array}$ \\
\hline & New York & $20(30 \%$ by 2003$)$ \\
\hline & Vermont & 32 \\
\hline & Wisconsin & $4 \%$ one child \\
\hline & & $14 \%$ two children \\
\hline & & $43 \%$ three children \\
\hline \multirow[t]{5}{*}{ Non-refundable credits } & Illinois & 5 \\
\hline & Iowa & 6.5 \\
\hline & Maine & 5 \\
\hline & Oregon & 5 \\
\hline & Rhode Island & 26 \\
\hline
\end{tabular}

Note: 1) The EITC in Minnesota is not linked to the Federal EITC.

* Source: Hotz and Scholz (2001), Table 2 
Figure A5: Welfare, Earnings and Income of a Single Parent with 2 Children in Wisconsin, 1999

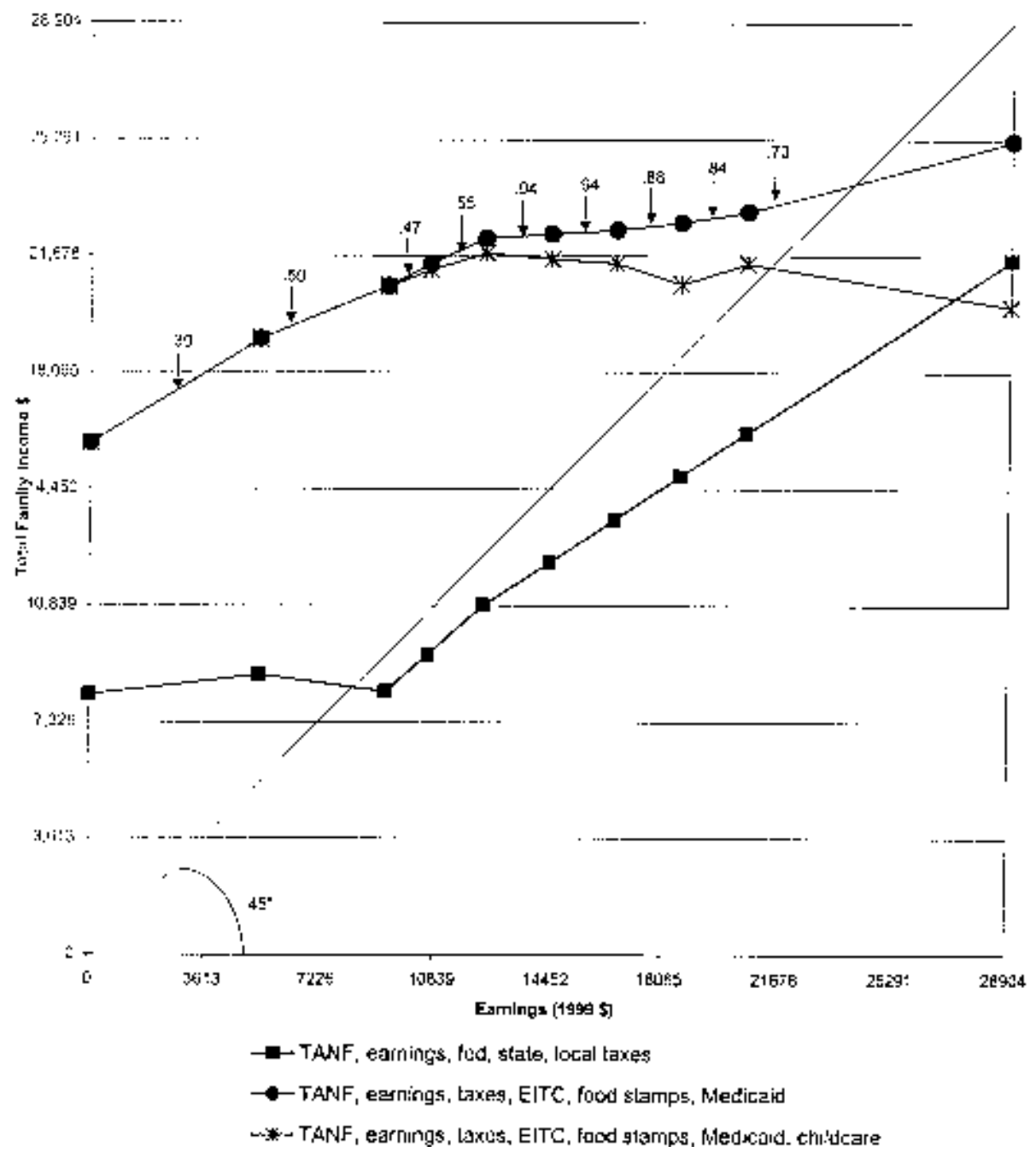

*Source: Haveman and Wolfe (2001), Figure 2. 
Figure A6: Taxes and Marginal Rates, Family of 4, Illinois, 1998

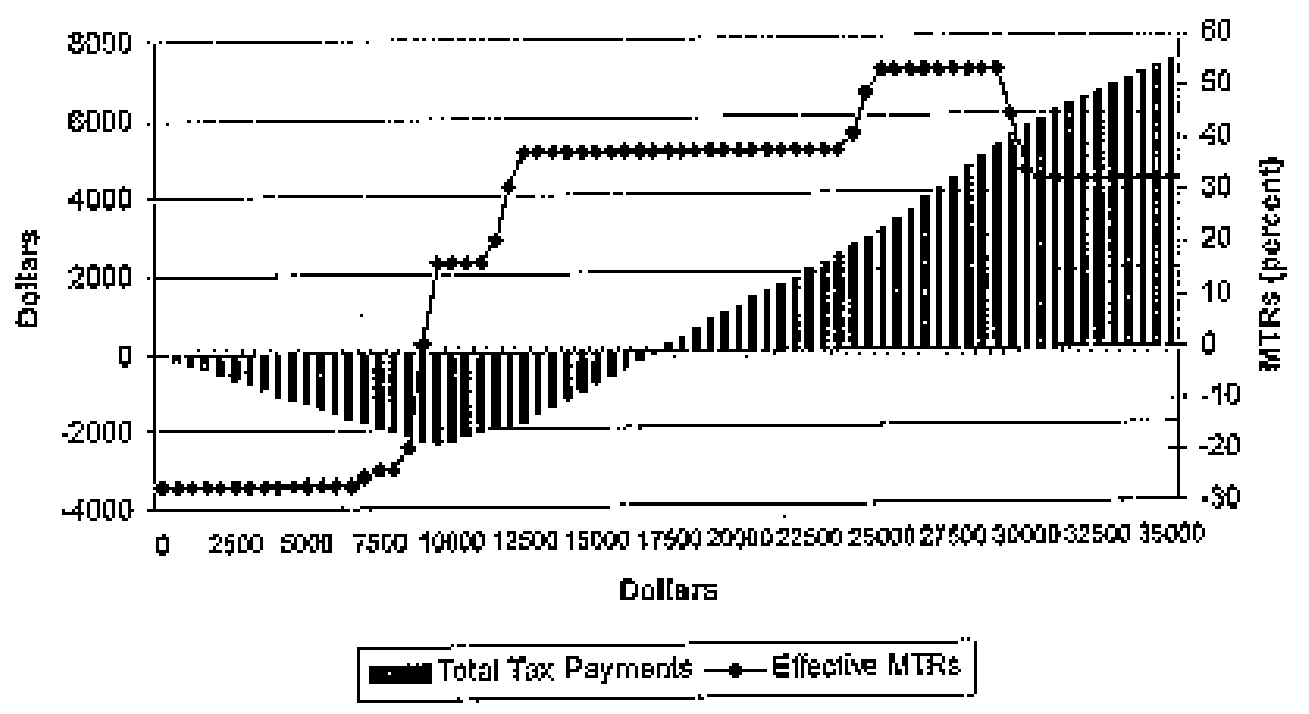

*Source: Hotz and Scholz, 2001, Figure 2a. 


\section{University Library}

\section{- M M N E R VA A gateway to Melbourne's research publications}

Minerva Access is the Institutional Repository of The University of Melbourne

Author/s:

Drago, R;Pirretti, A;Scutella, $R$

Title:

Work and family directions in the USA and australia: A policy research agenda

Date:

2007-02-01

Citation:

Drago, R., Pirretti, A. \& Scutella, R. (2007). Work and family directions in the USA and australia: A policy research agenda. JOURNAL OF INDUSTRIAL RELATIONS, 49 (1), pp.49-66. https://doi.org/10.1177/0022185607072241.

Persistent Link:

http://hdl.handle.net/11343/33661 